\title{
TENUN SONGKET NEGARA (SONGKET TANPA SAMBUNGAN) DARI KELOMPOK TENUN PUTRI MAS DI KECAMATAN JEMBRANA
}

\author{
Luh Candra Dewi ${ }^{11)}$ Made Diah Angendari ${ }^{2)}$ Ni Ketut Widiartini ${ }^{3)}$ \\ Program Studi Pendidikan Kesejahteraan Keluarga \\ Universitas Pendidikan Ganesha \\ Singaraja, Indonesia \\ e-mail : dewiluhcandra@gmail.com diah.angendari@undiksha.ac.id \\ ketut.widiartini@undiksha.ac.id
}

\begin{abstract}
ABSTRAK
Tujuan daripada skripsi ini adalah mendeskripsikan (1) proses dibuatnya tenun songket negara (songket tanpa sambungan), (2) motif tenun songket negara (songket tanpa sambungan), (3) penempatan komposisi motif kain tenun songket negara (songket tanpa sambungan) dari kelompok pertenunan Putri Mas di Kecamatan Jembrana. Penelitian deskriptif merupakan jenis penelitian yang digunakan. Adapun metode yang digunakan dalam pengumpulan data dilakukan dengan cara observasi dan wawancara. Penelitian ini dilakukan pada bulan Mei sampai Juni tahun 2020. Instrumen dalam penelitian ini adalah lembar wawancara dan lembar observasi. Dalam proses analisis data digunakan analisis deskriptif. Penelitian ini menunjukkan bahwa (1) Pada proses dibuatnya tenun songket negara (songket tanpa sambungan) terdiri dari beberapa tahap yaitu, proses pencelupan warna pada benang, proses pemintalan benang (Pengeliingan) dan penggulungan benang (Menghani), dan proses menenun menggunakan alat tenun yang telah domodifikasi dengan diberi nama Alat Tenun Negara. (2) Tenun songket negara (songket tanpa sambungan) terdiri dari motif songket negara bintang taburan, songket negara bintang kurungan, songket bun-bunan, songket djodog renes, songket kahyangan wulanperry, songket suarti sudana, songket kausa karana dan songket megawati soekarno putri yang dibuat dengan teknik songket dengan menggunakan benang warna. (3) Penempatan komposisi motif ditempatkan pada tempat yang sama secara posisi dan ukurannya yang termasuk dalam komposisi simetris. Secara keseluruhan tidak semata-mata ditempatkan satu motif hias, melainkan motif yang lebih banyak ditempatkan atau motif dominan menjadi motif utama sedangkan motif hias yang lainnya hanya menjadi motif pengisi dari seluruh bagian kain.
\end{abstract}

Kata kunci : tenun, songket tanpa sambungan, komposisi motif

\section{ABSTRACT}

This study aimed to describe (1) the process of making the songket negara woven cloth, (2) the songket negara woven cloth motif, (3) the placement of the composition of the songket negara woven cloth motif in the Putri Mas weaving group in Jembrana District, Jembrana Regency, Bali Province. The type of research used in this research is descriptive research. The data collection methods were carried out by observation and interview with the Putri Mas weaving group in Jembrana Regency. This research was conducted from May to June 2020 in Jembrana Regency. The research instruments were observation sheets and interview sheets. The data were analyzed using descriptive analysis. The results of this study indicate that (1) The process of making songket negara woven cloth consists of dyeing the colors on the yarn, the process of spinning the yarn (Pengeliingan) and winding the yarn (Menghani), and the weaving process using a weaving tool (ATBM) which has been modified with the name Negara Waving Tool (Alat Tenun Negara). (2) The songket negara woven cloth in the Putri Mas weaving group consists of songket negara bintang taburan motive, bintang kurungan, bun-bunan, djodog renes, kahyangan wulanperry, suarti sudana, kausa karana and songket megawati soekarno putri made with songket technique using colored thread. (3) The placement of the motif composition is in the same place in size and position which 
is included in the symmetrical composition. Overall, not only one decorative motif is placed, but the dominant decorative motif becomes the main motif, while the other decorative motifs are only complementary or filling motifs to fill the fabric field.

Key words: weaving, songket, motif composition.

\section{PENDAHULUAN}

Indonesia merupakan negara terkenal sebagai negara yang memiliki suatu kebudayaan yang mempunyai nilai estetik tinggi. Daerah Indonesia yang terdiri atas beragam suku masing-masing memiliki tenun dengan nama-nama yang khasnya tersendiri. Selain nama dan motifnya yang berbeda, tenun-tenun itu juga mempunyai fungsi dan nilai simbolis yang bermacammacam pula. Dapat dilihat misalnya, ulos dari daerah Batak, songket dari daerah Palembang, polengan dari daerah Sunda, lurik dari daerh Jawa Tengah, kain lamak dari daerah Bali, ikat dan sarung lau dari daerah Sumbawa dan Roti, tenun toraja dari daerah Sulawesi, palepai dan tampan dari daerah Lampung, dan masih banyak lagi (Risman, 1989:2).

Setiap daerah di Indonesia salah satunya Bali mempinyai ciri khas tersendiri dari kain endek dan tenun songket yang dihasilkan, sama halnya dengan kain tenun di Kecamatan Jembrana. Kelompok tenun di Kecamatan Jembrana yang telah Go Internasional dan mendapat sertifikat HKI atau Hak atas Kekayaan Intelektual adalah kelompok pertenunan Putri Mas. Berdasarkan hasil wawancara pada hari Sabtu, 12 Oktober 2019 dengan bapak Ketut Widiadnyana selaku ketua kelompok menyampaikan, kelompok pertenunan Putri Mas berusaha mewujudkan inovasi tenun dari motif yang dihasilkan, warna maupun teknik. Pada masa kini tidak lagi dibuat warna asli dari tumbuh- tumbuhan tetapi lebih banyak menggunakan zat-zat kimiawi seperti Naphtol, Basis, Procin dan lainnya (Kartiwa Suwati, 1996:72). Namun, berbeda halnya dengan Kelompok Tenun Putri Mas menggunakan pewarna alami sebagai bahan pewarna benang yang digunakan. Pewarna alami dipilih berdasarkan pertimbangan dari ketua kelompok tenun yang berpendapat bahwa pewarna alami merupakan pewarna yang aman digunakan sebagai bahan pewarna benang.

Dalam pembuatan motif hias songket negara pada kelompok tenun Putri Mas menggunakan teknik songket yaitu teknik menyilangkan benang pakan tambahan untuk membuat motif hias menjadi tampak menonjol. Pemilihan benang tambahan tidak menggunakan benang emas ataupun benang perak, melainkan menggunakan benang warna. Hal ini dikarenakan permintaan konsumen yang menginginkan songket yang ringan dan dengan harga yang ekonomis.

Penerapan motif pada tenun songket Negara (songket tanpa sambungan) menceritakan keanekaragaman sumber daya alam di derah Jembrana dengan berbagai bentuk motif antara lain motif songket negara bintang taburan, songket negara bintang kurungan, songket negara bun-bunan, songket negara djodog renes, songket negara kahyangan wulanperry, songket negara suarti sudana, songket negara kausa karana, dan songket negara megawati soekarno putri. Penempatan komposisi motif tenun songket yang dominan menjadi motif hias utama, sedangkan motif hias yang lain hanya menjadi motif tambahan. Komposisi motif yang utama ditempatkan pada bagian tengah kain, untuk pengaturan motif pelengkap atau isian diposisikan pada bagian pinggir kain tenun.

Dari segi alat tenun yang digunakan pada Kelompok Tenun Putri Mas dalam menenun adalah menggunakan Alat Tenun Bukan Mesin (ATBM) yang telah dimodifikasi dan diberi nama Alat Tenun Negara yang memiliki keunggulan yakni lebih mudah dalam pengoperasiannya yakni bisa dikerjakan dengan posisi duduk atau berdiri. Sesuai observasi awal dan hasil wawancara dengan Bapak Ketut Widiadnyana selaku ketua kelompok tenun, penulis tertarik melakukan penelitian dengan judul "Tenun 
Songket Negara (Songket Tanpa Sambungan) dari Kelompok Pertenunan Putri Mas di Kecamatan Jembrana".

\section{METODE PENELITIAN}

Penelitian deskriptif sendiri merupakan penelitian dasar tanpa adanya manipulasi terhadap objek penelitian dan berjalan seadanya yang diajukan demi mendeskripsikan kondisi dan kejadian yang terjadi (Nana, 2009:18). Sehingga penelitian deskriptif merupakan penelitian yang sesuai dengan jenis penelitian ini. Pelaksanaan penelitian dilakukan dalam kurun waktu 20 hari terhitung dari tanggal 19 Mei hingga 8 Juni, bertempat di kelompok pertenunan Putri Mas, Jalan Cendrawasih No.3, Desa Pendem, Kecamatan Jembrana, Kabupaten Jembrana, Provinsi Bali.

Banyak sumberdata dalam penelitian ini adalah berjumlah 3 orang yang meliputi 1 orang ketua kelompok tenun yang bernama I Ketut Widiadnyana, 1 orang dalam unit desain/motif yang bernama Ida Ayu Komang Arni dan 1 orang dalam unit pencelupan yang bernama Hengky Prasetyawan. Pengumpulan data dilaksanakan melalui : (a) observasi, (b) wawancara, (c) dokumentasi. Data yang diperoleh dilapangan mengenai masalah : proses pembuatan tenun songket negara, motif tenun songket negara dan komposisi penempatan motif pada pembuatan tenun songket negara pada kelompok tenun Putri Mas.

\section{HASIL DAN PEMBAHASAN}

Berdasarkan hasil observasi dan wawancara terhadap kelompok pertenunan Putri Mas, hasil menunjukkan bahwa proses dibuatnya tenun songket negara terdiri dari proses pencelupan warna, proses pemintalan benang dan penggulungan benang dan proses menenun. Proses pencelupan warna benang menggunakan bahan pewarna benang alami yang diekstrak dari kulit kayu, daun, akar, biji tumbuhan yang tumbuh disekitar daerah
Jembrana salah satunya kulit kayu mahoni. Selanjutnya benang yang telah diwarna dilanjutkan pada proses pemintalan benang yang dinamakan pengeliingan dengan fungsi menata benang pakan dengan cara menggulungkannya pada palet yang nantinya digunakan sebagai pembentuk motif hias dan proses penggulungan benang yang dinamakan menghani yang merupakan tahap awal sebelum menenun yaitu proses pembuatan helaian benang untuk dijadikan lungsi, kemudian benang lungsi digulung pada alat boom. Proses terakhir adalah menenun yang dilakukan menggunakan Alat Tenun Bukan Mesin (ATBM) yang telah dimodifikasi sehingga menghasilkan kain songket yang lebarnya $100 \mathrm{~cm}$.

Motif yang diterapkan pada kain songket negara antara lain motif bintang taburan, bintang kurungan, bun-bunan, djodog renes, kahyangan wulanperry, suarti sudana, kausa karana, dan megawati soekarno putri.

Penempatan motif hias tenun songket negara memiliki ciri masing-masing tergantung dengan nama motif hiasnya. Berikut ini ditampilkan penempatan komposisi motif yang diterapkan pada kain tenun songket seperti di bawah ini.

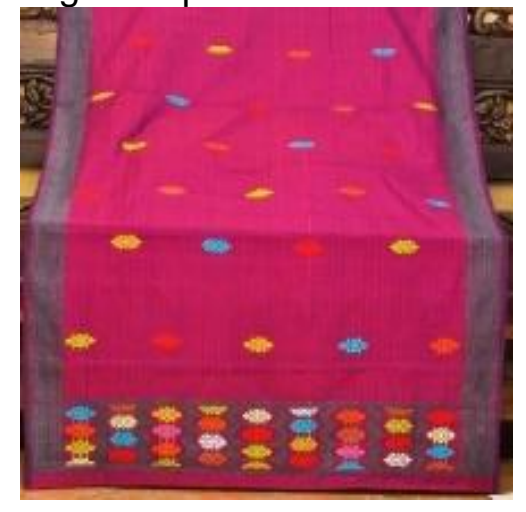

Gambar 1. Motif Bintang Taburan 
Jurnal Bosaparis: Pendidikan Kesejahteraan Keluarga Volume 12, Nomor 1, Maret 2021

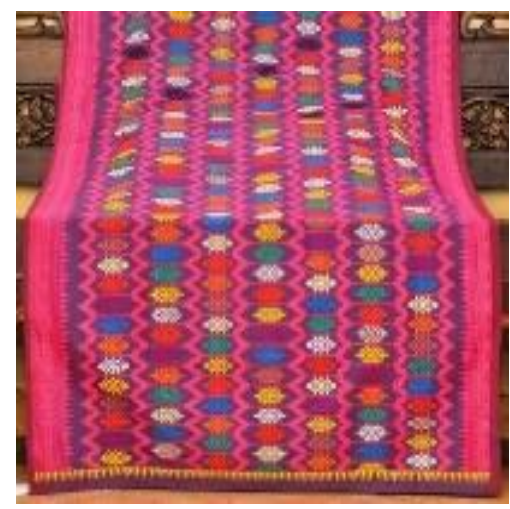

Gambar 2. Motif Bintang Kurungan

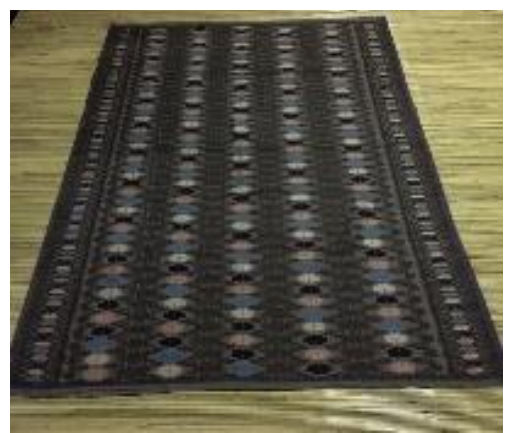

Gambar 3. Motif Bun-bunan

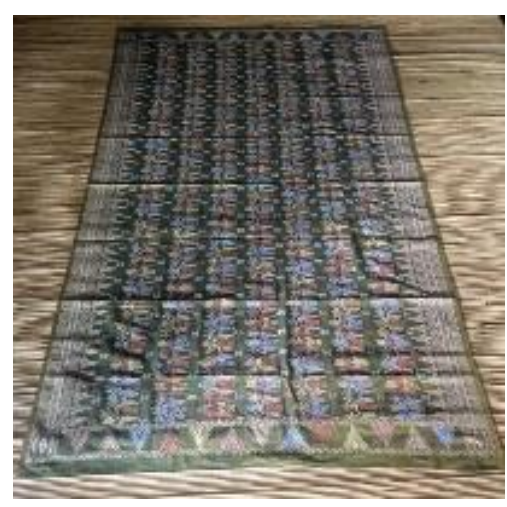

Gambar 4. Motif Djodog Renes

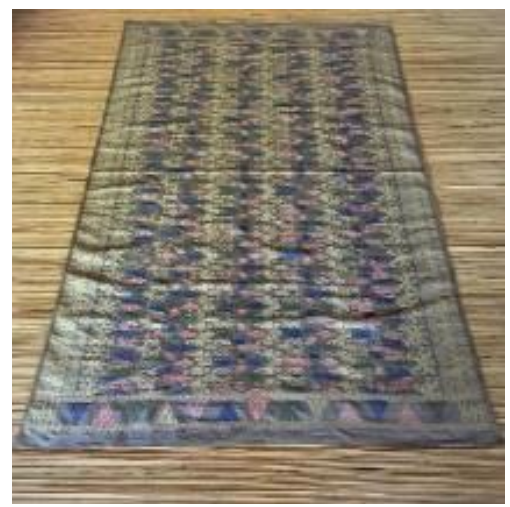

Gambar 5. Motif Kahyangan Wulanperry
p-ISSN : 2599-1434

e-ISSN : 2599-1442

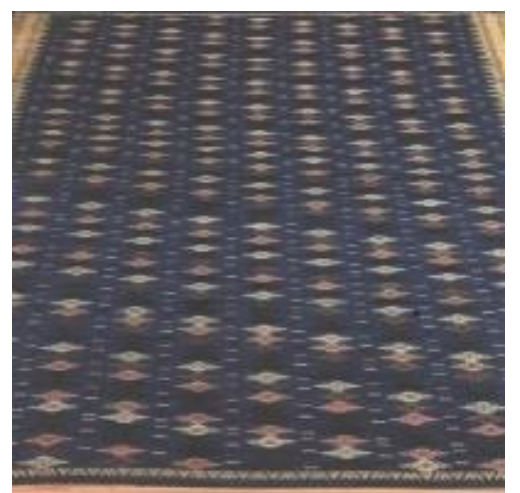

Gambar 6. Motif Suarti Sudana

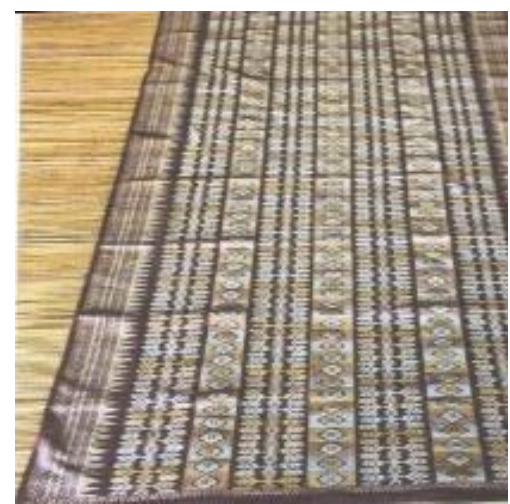

Gambar 6. Motif Kausa Karana

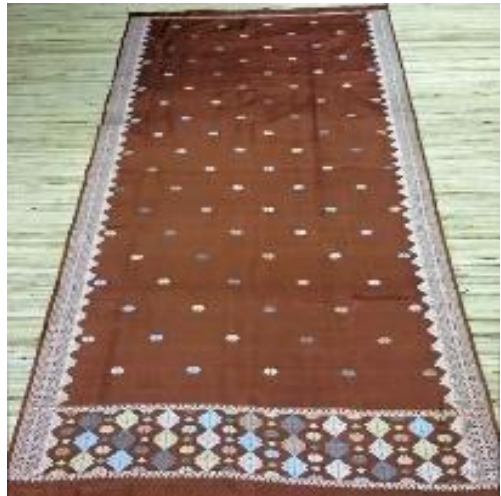

Gambar 7. Motif Megawati Soekarno Putri

\section{PEMBAHASAN}

Berdasarkan hasil penelitian dapat dibahas : (1) Seiring perkembangan teknologi serta melihat minat dan kebutuhan masyarakat yang semakin berkembang dengan penggunaan kain-kain tradisional, maka para pengerajin tenun terus membuat inovasi terbaru baik dari segi teknik, motif, alat tenun serta warna pada setiap pembuatan kain tenun. Hal ini didukung 
oleh hasil penelitian Guslinda dan Otang Kurniaman yahun 2016 dalam Jurnal Primary Program Studi Pendidikan Guru Sekolah Dasar Fakultas Keguruan dan IImu Pendidikan Universitas Riau, yang menyatakan dahulunya kain songket Siak dahulunya dibuat dengan menggunakan alat tenun sederhana yakni alat tenun Tumpu yang kemudian berkembang menjadi alat tenun Kek yang membutuhkan waktu lebih kurang satu setengah sampai dua bulan, dengan adanya pengembangan alat tenun (ATBM) membuat kegiatan bertenun menjadi lebih singkat dan dapat diselesaikan dalam waktu satu minggu. Begitu pula dengan kelompok tenun Putri Mas di Kabupaten Jembrana yang menggunakan alat tenun yang berbeda dengan alat pembuatan songket pada umumnya. Alat yang digunakan merupakan Alat Tenun Bukan Mesin (ATBM) yang telah dimodifikasi dan dinamakan alat tenun negara.

Kain tenun songket negara yang diproduksi oleh kelompok tenun Putri Mas merupakan kain songket yang tidak memiliki sambungan pada bagian tengahnya. Hal ini dikarenakan alat yang digunakan bukanlah alat tenun cag-cag atau alat yang menghasilkan kain dengan lebar yang kecil $(50 \mathrm{~cm})$ melainkan menggunakan Alat Tenun Bukan Mesin (ATBM) yang telah dimodifikasi dan menghasilkan kain yang lebih lebar dengan lebar $(100 \mathrm{~cm})$.

Jika dilihat dari segi bahan yang digunakan berasal dari alam mulai dari benang hingga bahan pewarna benang sehingga menghasilkan songket yang aman bagi tubuh maupun lingkungan dan nampak natural. Bahan pewarna yang digunakan berasal dari kekayaan alam yang ada di daerah Jembrana seperti, daun jati, mahoni, kunyit, mangrove, akar mengkudu, dan lainlain. Terdapat beberapa tahap yang dilakukan dalam proses menenun songket yaitu pencelupan warna benang, proses pengeliingan, proses menghani, proses nyukcuk, pembuatan motif dan proses menenun. Hal ini didukung oleh hasil penelitian yang dilakukan oleh Susana, Ismawan dan Nurlaili dalam Jurnal IImiah
Mahasiswa Program Studi Pendidikan Seni Drama, Tari dan Musik, bahwa ada beberapa proses yang harus dilakukan oleh penenun sebelum kain songket dapat ditenun pada ATBM. Proses tersebut antara lain Meuhani, Menyusuk, Menyisir, Membuat Motif dan Menenun. (2) Motif tenun songket yang dibuat bukan saja motif hias tradisional, tetapi sudah dibuat motif modern sesuai dengan kebutuhan konsumen. Seperti yang disampaikan oleh ketua kelompok tenun yakni I Ketut Widiadnyana, hal ini didasarkan atas faktor ekonomi, lingkungan dan kebudayaan daerah. Faktor ekonomi yang dimaksud yakni kebutuhan pasar akan adanya inovasi sehingga kelompok tenun Putri Mas terus menciptakan inovasi baru baik dari segi alat tenun maupun motif. Faktor lingkungan yang membuat diproduksinya motif tenun tradisional dan modern adalah dipengaruhi oleh wilayah atau daerah tempat tinggal yang memproduksi motif songket tradisional dan modern. Faktor yang terakhir adalah faktor kebudayaan yang ada di Bali yang berkaitan dengan upacara keagamaan. Adapun masing-masing motif yang dibuat di kelompok tenun Putri Mas telah memiliki sertifikat Hak Kekayaan Intelektual (HKI). Beberapa motif hias yang dibuat oleh kelompok tenun Putri Mas diantaranya songket negara bintang taburan, songket negara bintang kurungan, songket negara bun-bunan, songket negara djodog renes, songket negara kahyangan wulanperry, songket negara suarti sudana, songket negara kausa karana, songket negara megawati soekarno putri. Motif songket negara bintang taburan, songket negara bintang kurungan, songket negara bunbunan, songket negara djodog renes, songket negara kahyangan wulanperry, songket negara suarti sudana dan songket negara kausa karana merupakan motif songket tradisional. Sedangkan motif songket negara megawati soekarno putri merupakan motif songket modern yang dibuat berdasarkan atas nama Presiden Republik Indonesia yang ke 5 yakni lbu Megawati Soekarno Putri. Hal ini didukung oleh hasil penelitian yang dilakukan oleh 
Agustiana Wikrama Tungga Wika Atmaja dalam Jurnal Pendidikan Sejarah 2013, bahwa latar belakang pengerajin tenun songket di desa Sidemen memproduksi motif tradisional dan motif modern di latar belakangi oleh tiga faktor yakni faktor budaya, ekonomi dan lingkungan. Adapun motif tradisional yang dibuat oleh pengerajin tenun songket di desa sidemen yang dihasilkan berbentuk geometris yang dipadukan dengan motif-motif ornamen tradisional Bali yang sifatnya natural alam yaitu motif belah ketupat, motif pinggiran, motif mas-mas, motif rebong sari, motif merak, motif cakra, motif bunbunan, motif mawar, motif gunung, motif padang derman, dan motif naga. Sedangkan motif tenun songket modern diantaranya, motif ceplok mesir, motif bintang sempiar, motifpot pegat, motif pot merak dan motif kombinasi.

Dalam pembuatan motif hias pada tenun songket negara (songket tanpa sambungan) menggunakan teknik songket yaitu menyungkit, namun dalam pemilihan benang pada kelompok tenun Putri Mas lebih sering digunakan benang warna dibandingkan benang emas dan perak. Pewarna benang yang digunakan adalah dari bahan alam yang mudah ditemukan di daerah Jembrana seperti daun jambu, daun jati, kulit kayu mahoni, dan lain sebagainya. Hal ini didasarkan atas permintaan konsumen yang menginginkan songket yang lebih ringan, nyaman dipakai, harga yang lebih ekonomis, aman bagi tubuh dan aman bagi lingkungan. Hal tersebut didukung oleh penelitian yang dilakukan oleh Meylinda Mulyadi dalam Jurnal Teknik Industri 2009, yang menyatakan pewarna kimia pada kain songket memberi dampak buruk seperti pencemaran lingkungan sekitar perusahaan dan menyebabkan kanker kulit bagi pengguna kain songket. (3) Penempatan Komposisi motif tenun songket negara pada kelompok tenun Putri Mas secara keseluruhan terletak pada tempat yang sama secara ukuran dan posisinya termasuk dalam jenis komposisi simetris, namun tetap mempertahankan keseimbangan, kesatuan serta proporsi letak motif satu dengan lainnya. Secara umum tidak hanya satu jenis motif hias yang ditempatkan pada kain tenun, namun motif hias yang dominan menjadi motif hias utama walaupaun ada beberapa jenis motif hias yang menjadi pelengkap atau isianisian yang memenuhi bidang kain songket seperti bentuk taji-tajian yang menyerupai berbentuk geometris, tumbuh-tumbuhan (flora) maupun binatang (fauna). Hal ini didukung oleh hasil penelitian yang dilakukan oleh I Nyoman Sila dan I Dewa Ayu Made Budhyani dalam jurnal IImu Sosial dan Humaniora, vol. 2, No. 1, April 2013, yang menyatakan komposisi penempatan ragam hias objek utama, secara umum ditempatkan secara penuh pada bidang kain.

\section{SIMPULAN DAN SARAN}

Berdasarkan hasil penelitian yang telah dilaksanakan, maka dapat disimpulkan sebagai berikut : (1) Pembuatan tenun songket negara (songket tanpa sambungan) dari kelompok pertenunan Putri Mas melalui beberapa tahapan yaitu proses pencelupan warna benang, proses pemintalan benang (pengeliingan), penggulungan benang (proses menghani), dan proses menenun. Pada proses pencelupan warna benang digunakan pewarna alami, hal ini didasari atas sifat pewarna alami yang aman bagi tubuh dan lingkungan, selain itu pewarna alami dapat ditemukan dengan mudah di daerah Jembrana. (2) Motif hias tenun songket negara mengadopsi ciri khas daerah Jembrana yang terdiri dari motif tradisional dan motif modern seperti motif songket negara bintang taburan, songket negara bintang kurungan, songket negara bun-bunan, songket negara djodog renes, songket negara kahyangan wulanperry, songket negara suarti sudana, songket negara kausa karana, dan songket negara megawati soekarno putri. Dalam pembuatan motif hiasnya menggunakan teknik songket yaitu menyungkit, namun dalam pemilihan benang pada kelompok pertenunan Putri Mas lebih sering digunakan benang warna dibandingkan benang emas dan perak. Hal ini didasarkan atas permintaan konsumen yang menginginkan songket yang lebih 
Jurnal Bosaparis: Pendidikan Kesejahteraan Keluarga Volume 12, Nomor 1, Maret 2021

ringan, nyaman dipakai dan harga yang lebih ekonomis. (3) Penempatan komposisi motif tenun songket negara pada kelompok tenun Putri Mas secara umum diletakkan sama selaku ukuran dan warna sehingga termasuk kedalam jenis komposisi simetris, namun tetap disesuaikan dengan prinsipprinsip desain yang lainnya seperti kesatuan, proporsi, keseimbangan dan irama. Pemasangan motif songket negara bintang kurungan, songket negara bunbunan, songket negara djodog renes, songket negara kahyangan wulanperry, songket negara suarti sudana dan songket negara kausa karana ditempatkan secara penuh. Sedangkan motif songket negara bintang taburan dan songket negara megawati soekarno putri hanya dipenuhkan pada bagian pala atau hiasan bagian depan saat menggunakan kamen sedangkan pada bagian sisanya ditata berjarak sehingga terdapat beberapa bidang yang kosong.

\section{SARAN}

Berdasarkan pembahasan dan simpulan, dapat disajikan saran berupa : (1) Diharapkan produksi tenun songket Negara (songket tanpa sambungan) ini lebih ditingkatkan dan dapat dijangkau oleh masyarakat Jembrana. (2) Motif dari tenun songket Negara diharapkan dapat lebih diperbanyak lagi, baik dari segi kombinasi maupun jenis motif yang digunakan tanpa harus menghilangkan ciri khas dari tenun songket negara yang sudah ada sebelumnya. (3) Komposisi motif pada pembuatan tenun songket negara pada kelompok tenun Putri Mas di Kabupaten Jembrana diharapkan dapat lebih berkembang nantinya, baik dari segi peletakan motif hias maupun kombinasikombinasi yang digunakan tanpa menghilangkan ciri khas dari kain tenun songket negara yang sudah ada sebelumnya.

\section{DAFTAR PUSTAKA}

Atmaja, Agutiana W. T. W. 2013. Perkembangan Motif Tenun Songket Di
p-ISSN : 2599-1434

e-ISSN : 2599-1442

Desa Sidemen, Karangasem, Bali (Potensinya Sebagai Sumber Belajar Sejarah Kebudayaan Di SMA). Tersedia pada Ejournal Pendidikan Sejarah Volume 1 2013, www.undiksha.ac.id.

Candra Dewi, I. G. A. 2014. "Tenun Songket Inovasi Pada Industri Tenun Putri Ayu Kecamatan Blahbatuh Kabupaten Gianyar Provinsi Bali". Jurnal Bosaparis, Vol. 2, No 1.

Dharsono. 2007. Estetika. Bandung: Rekayasa Sains.

Dms. 2018. Alat Tenun Bukan Mesin (ATBM)/ Kasuksak. Tersedia pada https://lpkanugrah.co.id/alat-tenunbukan-mesin-atbm-kasuksak/ (diakses tanggal 20 Februari 2020)

Djoemana, Nian. 2007. Lurik garis-garis Besar Bertuah. Jakarta: Djamban

Fauzi, Eko Ramdi. 2013. "Prinsip-prinsip Menggambar Model". Tersedia pada https://sumberbelajar.belajar.kemdikbu d.go.id/sumberbelajar/tampi/Menggam bar-Model-2017/index.html (diakses tanggal 1 Mei 2020)

Guslinda dan Otang Kurniaman. 2016. Perubahan Bentuk, Fungsi dan Makna Tenun Songket Siak pada Masyarakat Melayu Riau. Tersedia pada Ejurnal Primary Program Studi Pendidikan Guru Sekolah Dasar Fakultas Keguruan dan IImu Pendidikan Universitas Riau Volume 5 2016, www.unri.ac.id.

Kabar Dewata. 2004. Songket Bali Pada Umumnya. Tersedia pada www.kabardewata.com/berita/berita...k ain-tenun-songket-bali-html. (diakses pada tanggal 12 November 2019).

Kamus Besar Bahasa Indonesia. 1991. Jakarta: PT Rineka Cipta Kusuma, Atmaja, dkk. 1990-1991. Perjalanan 
seni Rupa Indonesia, dari Zaman Prasejarah Hingga Masa Kini. Panitia Pameran KIAS.

Kartiwa, S. 1986. Kain Songket Indonesia. Jakarta: Djamban.

Kartiwa, S. 1996. Kain Songket Indonesia. Jakarta: Djamban.

Marah, Risman. 1982. Album Tenun Tradisional. Jakarta: Departemen Pendidikan dan Kebudayaan.

Mulyati, Meylinda. 2009. Analisis Pewarna Alami Pada Industri Tenun Songket di KHM Husin Rahman Songket Palembang. Tersedia pada Ejournal Teknik Industri Volume 92009. www.academia.edu

Nyo, Agustien dan Endang Subandi. 1980. Pengetahuan Barang Tekstil. Jakarta: Departemen Pendidikan dan Kebudayaan.

Leigh, Barbara. 1989. Tangan-tangan Terampil Aceh. Jakarta: Djamban.

Poewadarminta. 1976. Songket Nusantara. Jakarta

Sanyoto, Sadjiman Ebdi. 2005. DasarDasar Tata Rupa Desain. Yogyakarta: CV Arti Bumi Intaran.

Sastra, Rantinah. 2008. Ragam Hias Nusantara. Klaten: PT Intan Pariwara

Setiawati, Rahmida, dkk. 2007. Seni Budaya Bogor. Jakarta: Yudhistira

Sila, I. N. dan I. D. A. M. Budhyani. 2013. Kajian Estetika Ragam Hias Tenun Songket Jinengdalem, Buleleng. Tersedia pada Ejournal IImu Sosial dan Humaniora Volume 2 2013, www.undiksha.ac.id.

Sugiarto, Hartanto. 1980. Teknologi Tekstil. Jakarta: Pradnya Paramita
Sugiyono. 2016. Metode Penelitian Kuantitatif, Kualitatif dan $R$ \& $D$. Bandung: Alfabeta.

Suhersono, H. 2005. Desain Bordir Motif Geometris. Jakarta: PT Gramedia Pustaka Utama.

Sukmadinata, Nana Syaodih. 2009. Metode Penelitian Pendidikan. Bandung: PT Remaja Rosdakarya.

Suryani, Tatik. 2008. Perilaku Konsumen (Implikasi Pada Strategi Pemasaran. Surabaya: Graha IImu

Susana, dkk. (2018). Proses Pembuatan Kain Songket Tenun Di Ujung Tanah Kecamatan Samadua Kabupaten Aceh Selatan. Tersedia pada Ejournal IImiah Mahasiswa Program Studi Pendidikan Seni Drama, Tari dan MusikVolume III, Nomor 2 (hlm.200-206), www.jim.unsyiah.ac.id.

Susanto, Mikke (2011). Diksi Rupa (Kumpulan Istilah dan Gerakan Seni Rupa). Yogjakarta: DictiArt Lab.

Widya, Ni Wayan. 2017. Tenun Songket Ngalam Pada Industri Tenun Pelangi Kecamatan Sidemen Kabupaten Karangasem. Tersedia pada Ejournal Bosaparis Undiksha Volume 8 2017, www.undiksha.ac.id.

Yandri. 2014. Tenun Songket Pandai Sikek Dalam Budaya Masyarakat Minangkabau. Tersedia pada Ejournal IImiah IImu-ilmu Humaniora Volume 13 2014.

Zumar, Dhorifi. 2007. Tenun Tradisional Indonesia. Jakarta: PT. Dian Rakyat. 